\title{
Source type evaluation of polycyclic aromatic hydrocarbons (PAHs) in surface sediments from the Muar River and Pulau Merambong, Peninsular Malaysia
}

\begin{abstract}
This article is the most recent report of polycyclic aromatic hydrocarbons (PAHs) in the Muar River and Pulau Merambong, Peninsular Malaysia. A total of 16 priority pollutant PAHs in addition to methylphenanthrene among alkylated PAHs were analyzed in surface sediments during May 2013. Total PAHs ranged from 212 to 440 and 151 to $412 \mathrm{ng}$ gi $1 \mathrm{dw}$ in sediments from the Muar River and the Pulau Merambong, respectively. The Muar River showed an increasing trend of PAH concentrations, while no previous data exist for the Pulau Merambong. Generally, mixed petrogenic and pyrogenic sources of PAHs with predominance of the latter were detected in the study area. Effective management of oil pollution has caused a drastic decrease in petrogenic sources of PAHs.
\end{abstract}

Keyword: Pollution sources; Malaysia; Pyrogenic; Petrogenic; Diagnostic ratios 